\title{
冷凍創治癒過程の組織化学的研究
}

\author{
松村隆司
}

\section{Histochemical study on healing process of the oral mucosal wound of the rat following cryotherapy}

Takashi Matsumura

\begin{abstract}
緒
言

冷凍外科は近年口陵外科領域において 各種奖患 ${ }^{1 \sim 7)}$ に 詨して広く用いられ，劇的な効果が報告されている，し かし結果は必ずしす一定していない，そこでこれに対し て種々の基礎的な実験8 11が行われ，本学に扎いてる渡 辺 ${ }^{22}$ は凍結時の温度勾配について，また天羽 ${ }^{13)}$ は凍結後 の骨組織の変化を, 橋本 ${ }^{14)}$ は神経線維に対する影響を,

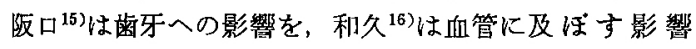
を、さらに Iida ${ }^{17)}$ は炎症組織を凍結したあとの経過に ついて報皆している.

凍結後にみられる組織の変化には著明な浮腫の出現や 組織修復がほぼ終わるまで筫死上皮が創部をおおってい るなど特異な経過が認められる，特に臨床的には頓や舌 などロ腔軟組織を凍結したときに浮尰が著しく患者に不 快感や不安感を与える場合が多く，この点患者管理面で 配虑を要する。しかし一方，冷涷創には症痕形成の少な いことが観察されており，これは本療法の好ましい一面 である。

今回わたくしは倲結創におけるこの特珙な修復過程を 組織学的扰よ゙組織化学的に検索した.

\section{実験材料と使用器機}

\section{1. 実験動物}

体重 $200 \mathrm{~g}$ 前後の雄性ウィスター系ラットを使用し, 実験期間中はオリエンタル固形飼料と水道水を用いて飼 充した。

\section{2. 凍結用器機}

Frigitronics 社の冷凍外科装直（写直1-A）を使用し た。この装瘨は亚酸化窒素を冷媒とし，各種プローべが

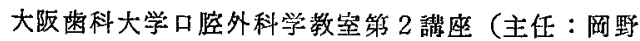
博郎教授)

Second Department of Oral Surgery, Osaka Dental University (Chief: Prof. Hakuro Okano) 受付日：昭和53年 1 月 25 日

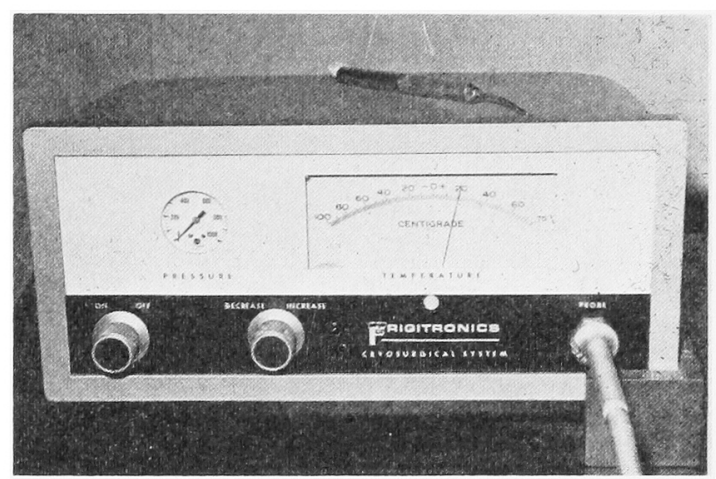

写真 1-A 冷凍外科装監 (Frigitronics Cryosurgical System)

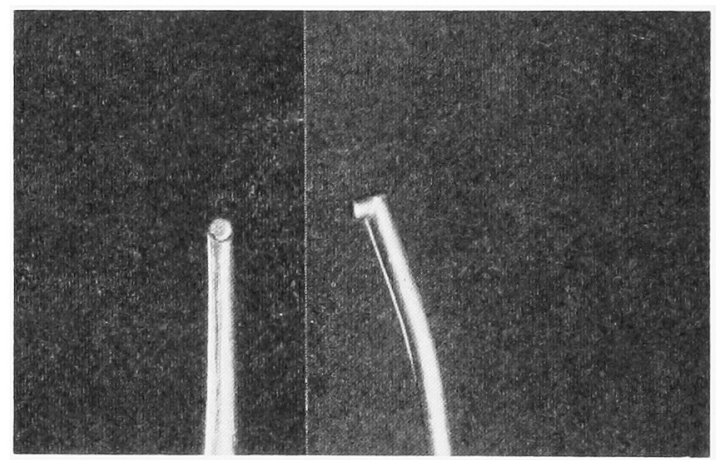

写真 1-B 凍結用ブローペ（直径 $5 \mathrm{~mm}$ の円柱形）

用意されているので症例により使いわけが可能である. 今回使用したプローべ（写真1-B）は直径 $5 \mathrm{~mm}$ の円 柱形で T-hermister が装備され，Footcontroler により 制御される。

\section{3. 温度測定用器機}

Bailey 社の CRYO-THERMOMETER BAT-5（写 真 2-A）を使用した，この器機は直径 $0.32 \mathrm{~mm}$ の銅一 ニッケル熱電対針（写真 2-B）を装備し，測定範囲は $100 \sim-200^{\circ} \mathrm{C}$ までで，その测定愦差は $1 \%$ 以内であ ๖. 


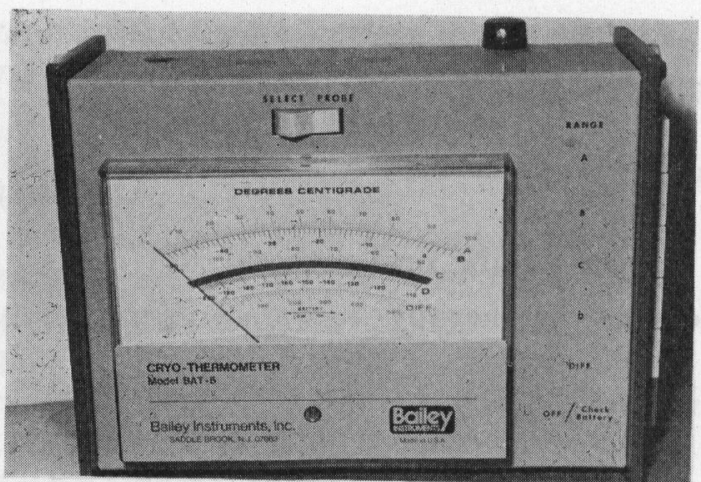

写真 $2-\mathbf{A}$ 温度計

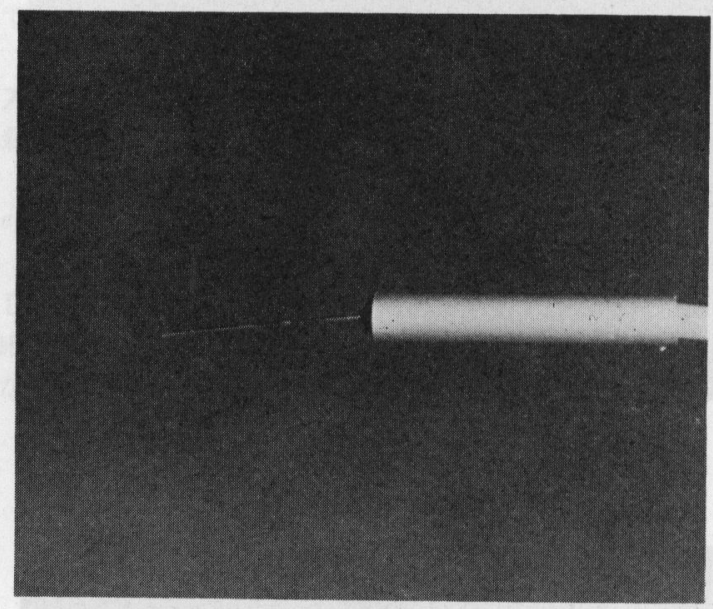

写真 2-B 温度測定用の熱電対針（直径 $0.32 \mathrm{~mm}$ )

\section{実 験 方 法}

\section{実験 I プローベの冷凍能力}

1) プローベの表面温度 : 被験体に圧接されるプロー べ表面の温度をプローべに直接，熱電対針を接触させて 測定し, 凍結器機の温度計に表示されるプローべ内部の 温度との誤差を調べた。

2) 組織内温度 : 外頓部より温度針をプローべ直下に 達するように刺入し, 温度計とプローべの距離を $1 \mathrm{~mm}$ と $2 \mathrm{~mm}$ にして測定した。

\section{実験 II 組織の変化}

クロロホルム吸入麻酔下でラット顂粘膜に圧接法によ り 1 分間凍結を行い, 術後 24 時間, $2 ， 3 ， 4 ， 5 ， 7 ， 10$, 14 打よび 20 日に扮の拈の 3 匹ずつ屠殺し試料を採取し た.

1) 組織学的観察 : 通法によりへマトキシリン・エオ ジン（以下 H-E と略す）拈よびワン・ギーソン染色を 行った。

2) 組織化学的観察: 凍結切片は Naphtol AS-MX

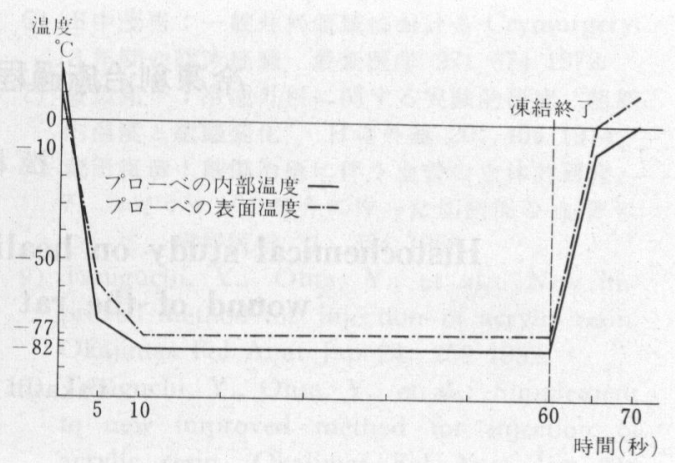

図11 分間凍結を行ったときのプローべ表面と 内部の温度

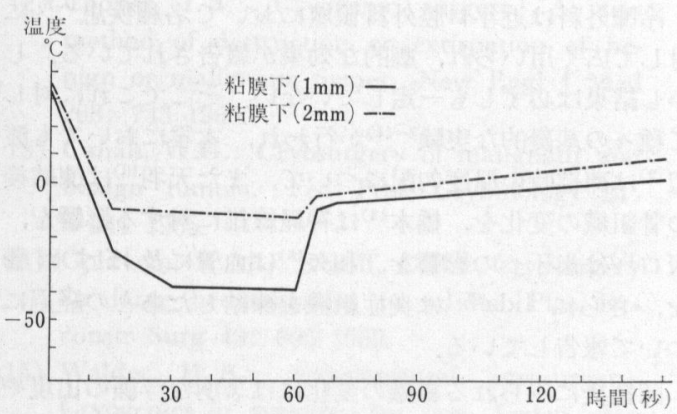

図 21 分間凍結を行ったときの組織内温度

を基質とする Burston の方法で alkaline phosphatase (以下 ALPase と略す) を，また Nitro-BT を electron accepter とする Mori の方法で glucose-6-phosphate dehydrogenase (以下 G6PDH と略す) を検索した。

\section{実 験 結 果}

\section{実験 I プローベの冷凍能力}

1) プローベの表面温度 : 冷却を行った場合のプロー べ表面の温度は, 器機の表示するプローべ内部の温度よ り約 $5^{\circ} \mathrm{C}$ 高い值を示す (図1).

2) 組織内温度 : 室温 $20 \pm 0.5^{\circ} \mathrm{C}$, 湿度 $60 \pm 5 \%$ に おいて $-20^{\circ} \mathrm{C}$ の温度域は粘膜下 $1 \mathrm{~mm}$ と $2 \mathrm{~mm}$ の間 の深さに達していた（図2）。

\section{実験 II 組織の変化}

\section{1) 組織学的観察}

凍結後24時間 : 凍結部を取り囲むように炎症細胞浸潤 が認められ, 特に好中球が多い，上皮の一部は融解壊死 を起こし染色性の低下がみられるとともに，毛細血管の 破綻と内皮細胞の核の消失, また一部に水腫が認められ る(写真 3 ).

凍結後 2 日：凍結部を取り囲む炎症細胞浸潤が著明と 


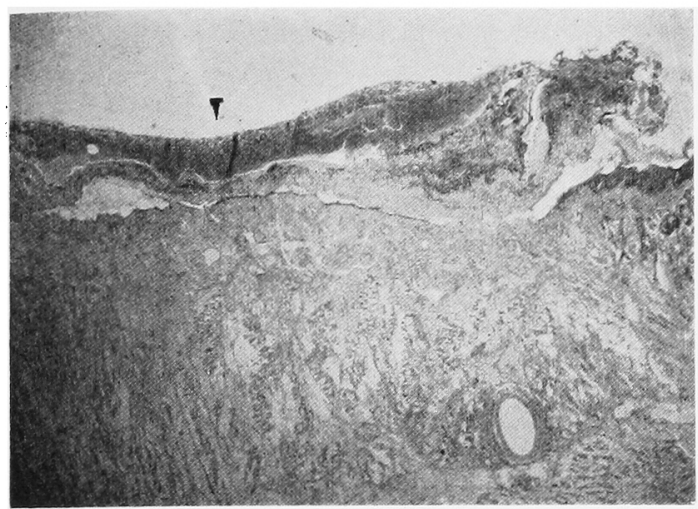

写真 3 凍結後 24 時間 (H-E 染色) V凍絬部

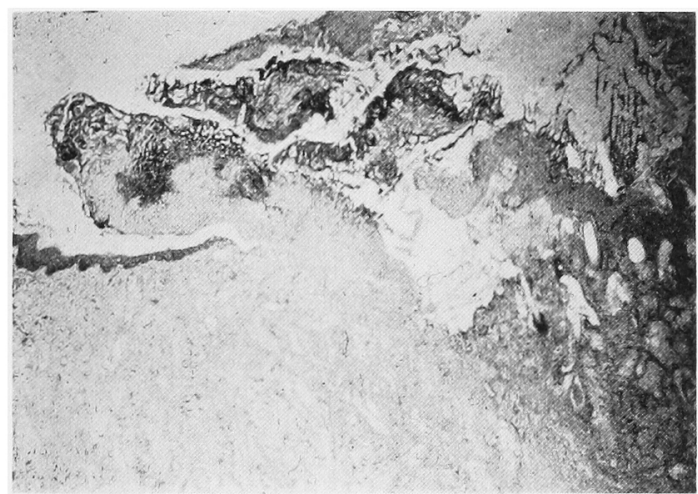

写真 4-A 凍結後 2日 (H-E 染色)

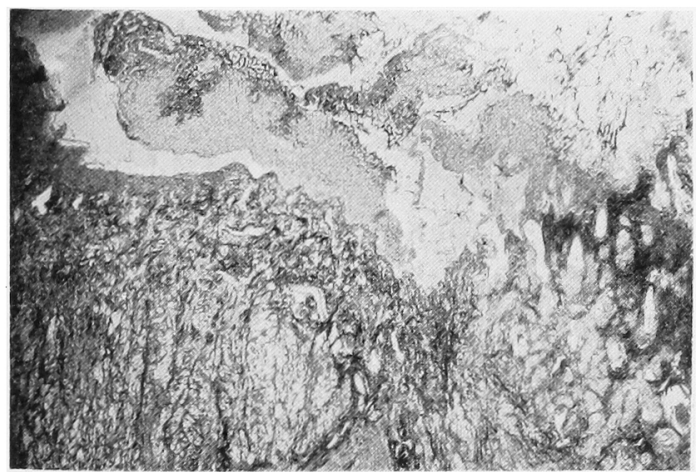

写真 4-B 谏結後 2 日（ワン・ギーソン染色）

なり，凍結部全域に強い水腫かみられる。また皮なら びに皮下組織は融解壊死が著明となり，版皮となって創 部を怙扮っている（写真 4-A）。 ワン・ギーソン染色に 括いても凍結部の上皮ならびに直下の皮下組織は無構造 になり，さらにその值下には強い水隀がみられるが，間 質にはまだ新生したコラーゲン線維を認めない（写直 4-B).

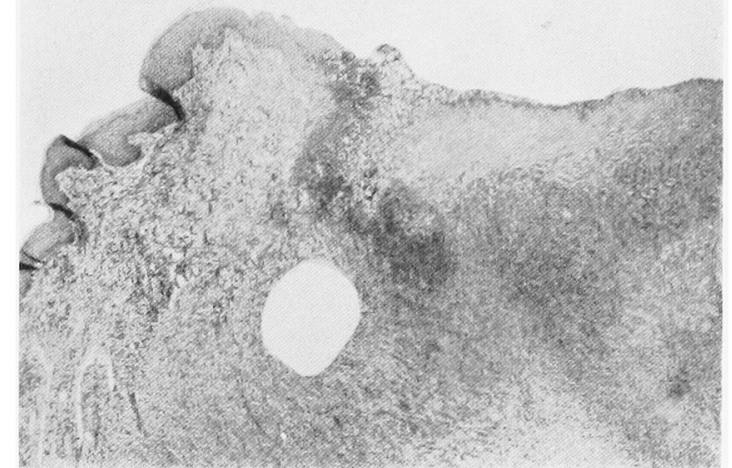

写真 5-A 凍結後 3 日（H-E 染色）

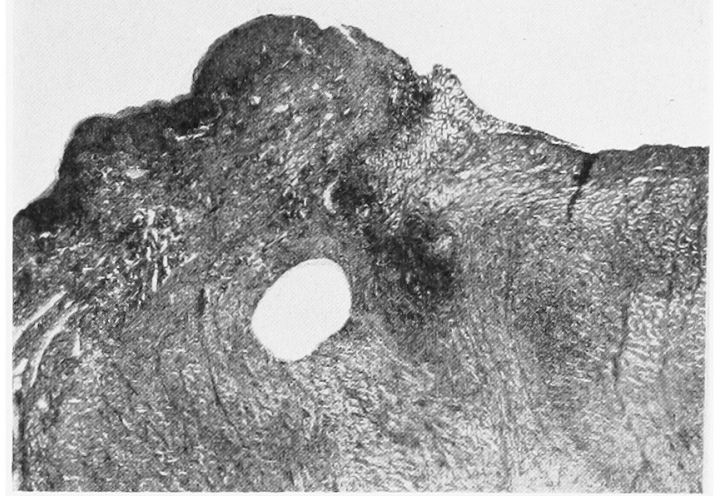

写真 5-B 谏結後 3 日（ワン・ギーソン染色）

凍結後 3 日：凍結部を取り囲む炎症細胞浸潤は帯状に 幅広く認められる，雄皮はまた゚残存して創部を㧍招って おり，この直下の間質には水腫が著明である（写真 5A)。またワン・ギーソン染色に招いて間質にはまだ新 生のコラーゲン線維の出現を認めない(写真 5-B).

凍結後 7 日：痵皮恃剩離脱落し始め，その下に創縁部 より新生の上皮が伸展している。 また电細血管の新生と ともに紡鉭形の大きな核を有する線維芽細胞がみられる (写真 6-A)。 ワン・ギーソン染色に おいても創縁部よ り新生した上皮の伸展がみられ，また間質に幼若なコラ ーゲン線維の出現が認められる(写真 6-B).

凍結後14日：創部は新生した上皮で括㧍われて括り， その直下の間質はコラーゲン線維で粗に啮たされている (写真 7-A)。 ワン・ギーソン染色においても新生され たコラーダン線維が間質部を粗に満たしている（写真 7-B).

凍結後20日：創部を打打う新生された上皮の厚さむ周辺 部正常上皮と同様の厚さになり，また上皮下はコラーゲ 


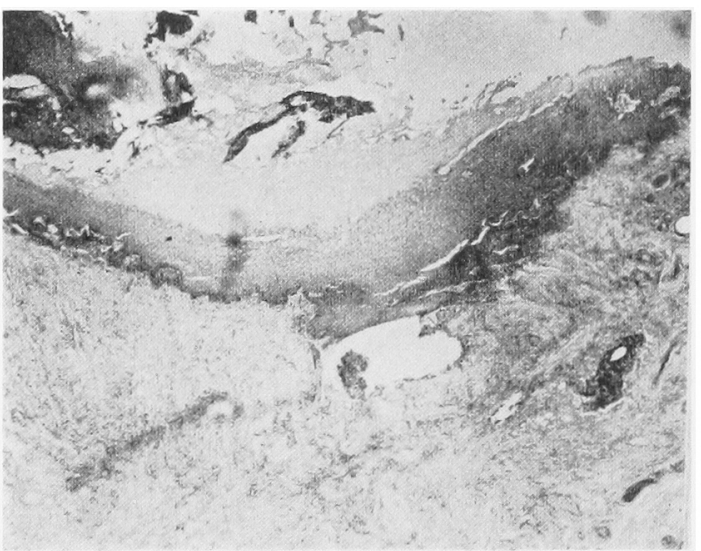

写真 6-A 凍結後 7 日（H-E 染色）

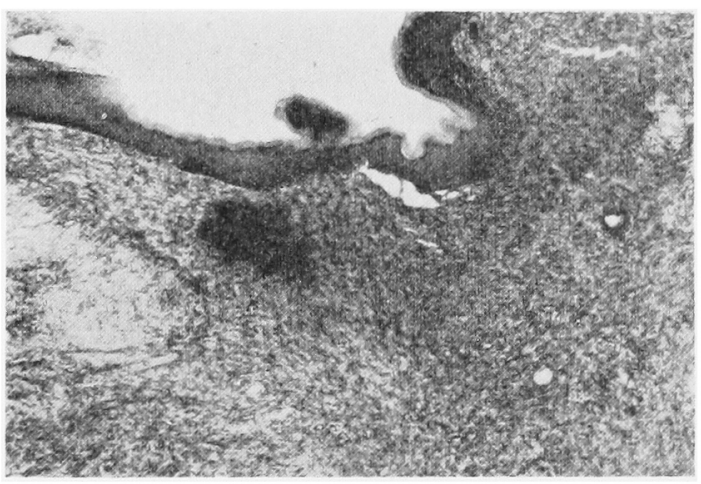

写真 7-A 凍絬後14日 (H-E 染色)

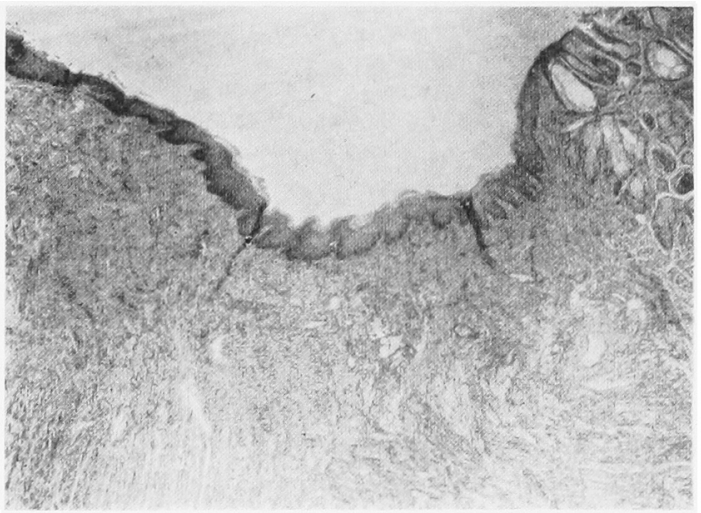

写真 8-A 凍結後20日（H-E 染色）

ン線維により満たされている（写真8-A）。ワッ・ギー ソン染色で間資部はすでに成热したコラーゲン線維で満 たされている(写真 8-B).

\section{2) 組織化学的観察}

凍結後24時間：涷結部を取り国む炎症細胞 澗 部に ALPase 活性が認められる（写真 9).

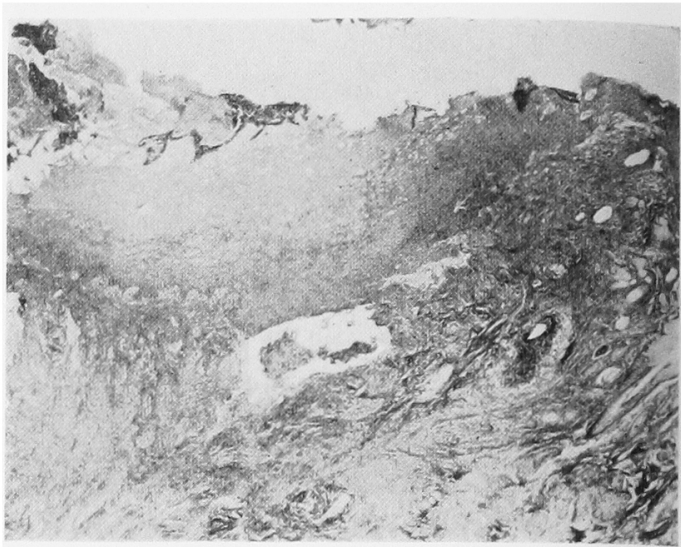

写真 6-B 凍結後 7 日( ( ソ・ギーソン染色)

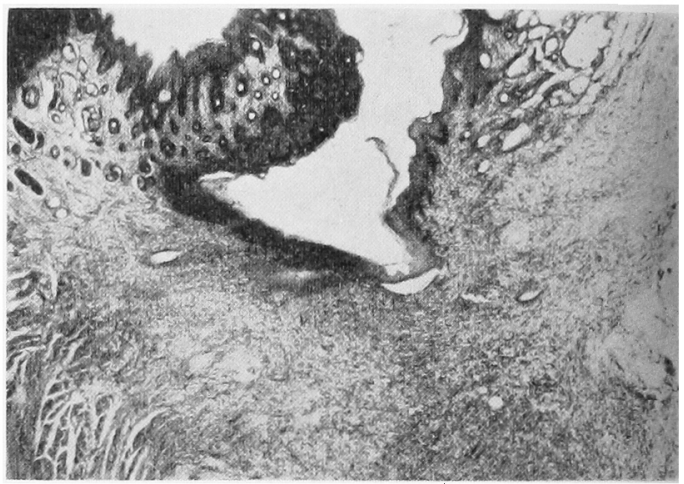

写真 7-B 凍結後14日（ロン・ギーンン染色）

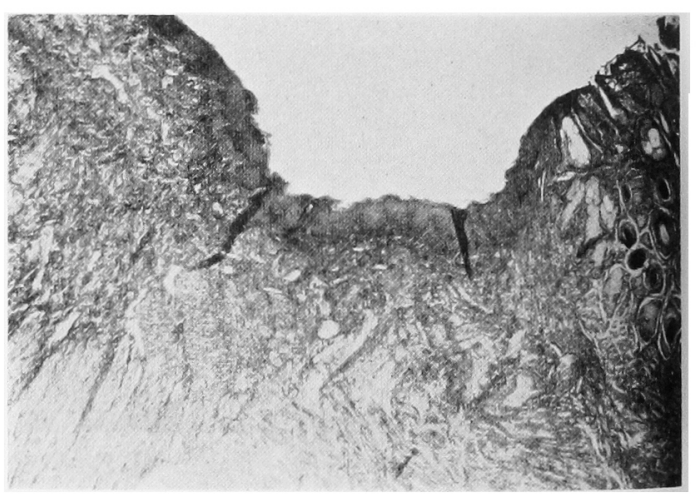

写真 8-B 涷結後20日（ワン・ギーンン染色）

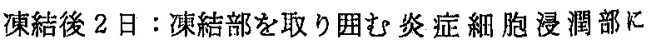
ALPase 活性が細い州状浔められる（写直 10）。

准結後 3 日: 炎症細胞浸潤部の ALPase 活性は幅の 公い需状に認められる（写真 11）。

凍結後 4 日: 炎症細胞漫潤部に帯状にみられた ALPase 活性陽性部はこの時期より活性の低下および消 


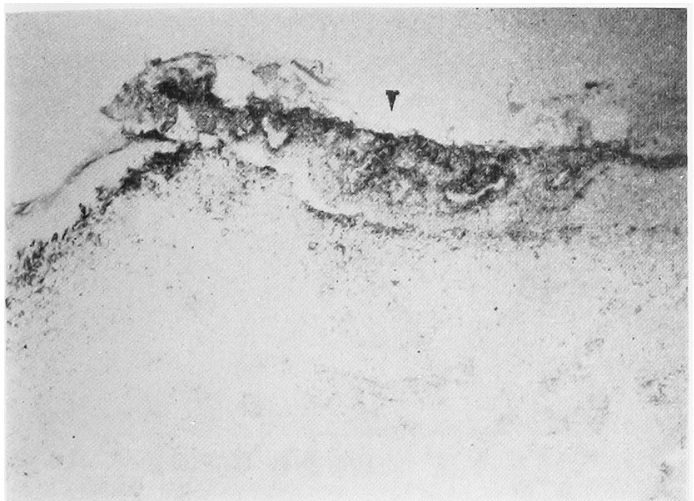

写真 9 凍結後24時間 ALPase， 凍結部

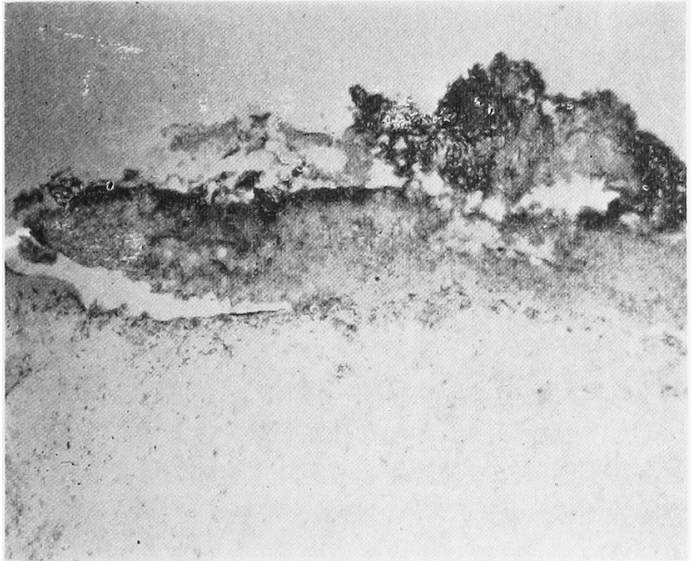

写真 10 棵結後 2 日 ALPase

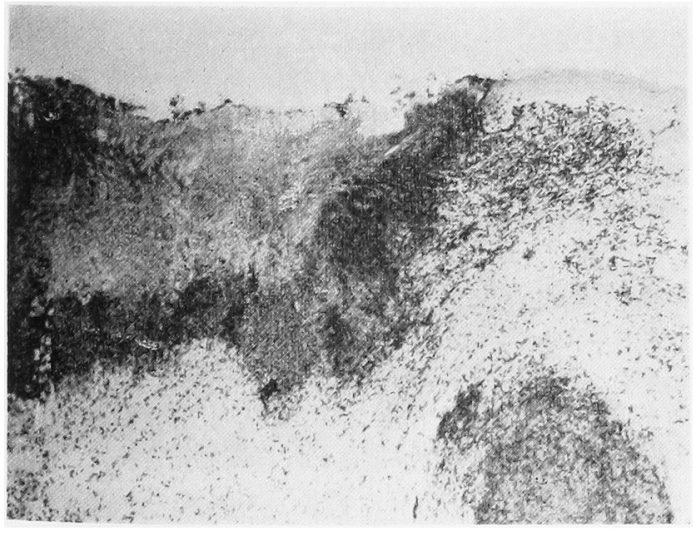

写真 11 凍結後 3 日 ALPase

退㖽向を示し始める（写真 12）。

倲結後 7 日：一時消退した ALPase 活性がこの恃期 より再びュラーゲン合成の肚盛な間質部隹められる (写真13)。一方，伸展しつつある上皮に G6PDH 活性

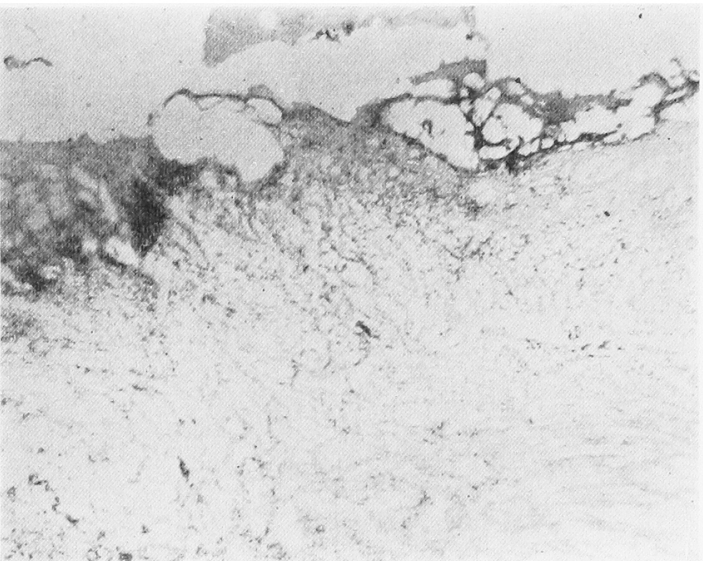

写真 12 凍結後 4 日 ALPase

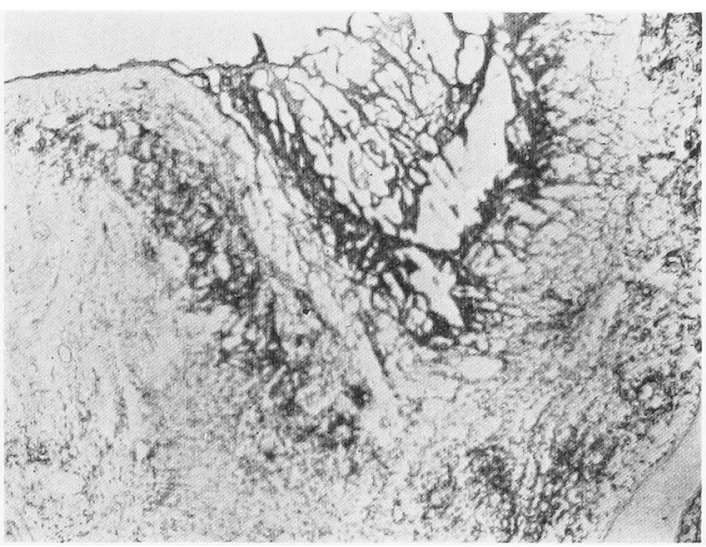

写真 13 淉結後 7 日 ALPase

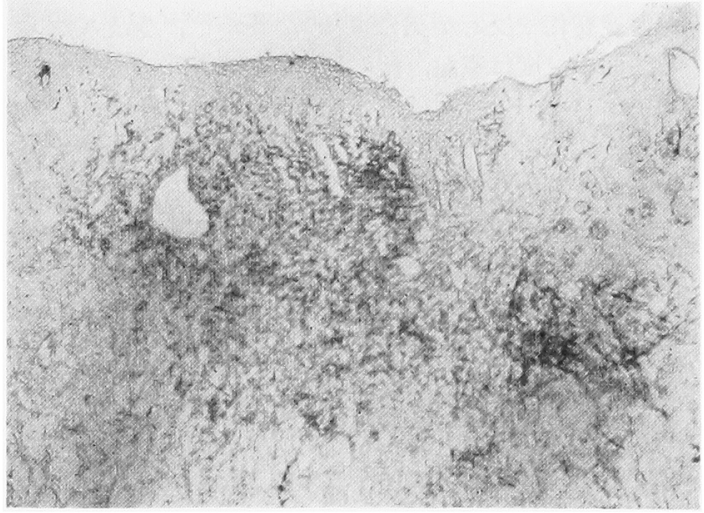

写真 14 凍結後14日 ALPase

を諗める。

東結後14日：釗部は新生された上攴で沶执われている が，上皮下では ALPase 活性が依然として残っている （写真14）。また新生されだ上皮の顆粒層には $\mathrm{G} 6 \mathrm{PDH}$ 


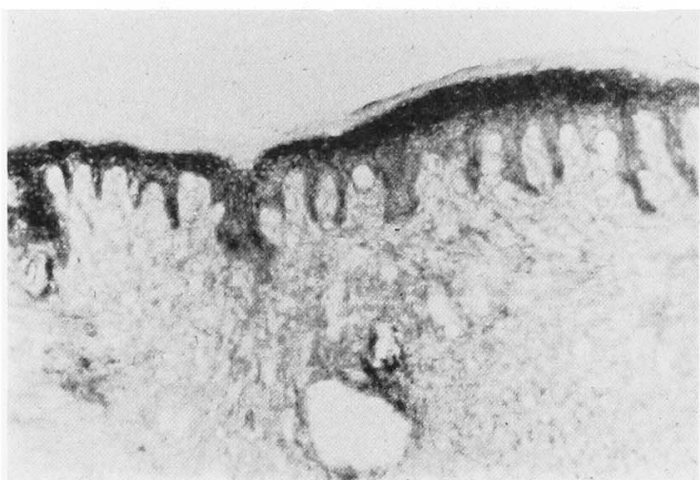

写真 15 凍結後14日 G6PDH

の強い活性が残っている(写真 15).

凍結後20日：間質部にみられた ALPase 活性は消退 している。また上皮層にみられた G6PDH 活性も周团 の正常上皮と同様の活性に復している（写真 16）。

\section{考察}

Fraser $^{18)}$ おび岡野ら ${ }^{199}$ は冷涷潦法について術中, 術 後の疼痛がなく出血および感染もみられず，汪とんどの 症例付して外来で短時間内に行うことができ，乙かも 局所凍結による全身的な影響はきわめて少ないので，幼 児や高齢者さらに全身衰弱の著しい患者にも繰り返し行 えると述べている。一般に超低温により組織が破壞され る機構にはいくつかの説年 23) があり, Whittaker ${ }^{9}$, 法

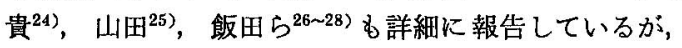

現在のところ定説はないようである。ブローべの冷凍 能29,30), 組織の種類打よび解剖学的な環境因子により組 織の温度变化や反応が異なり ${ }^{8,10,11,27,31,32)}$, 加えてプロ 一へ表面の温度は室温, 湿度など外部環境に左右され,

さらにブローべと生体組織の接触状態も冷涷効果を左右 する因子である，そこで本実験に使用する冷涷装置の能 力を調べるために臨林で広く行われている压接法33)を用 い1分間組織涷結を行い, $-20^{\circ} \mathrm{C}$ の臨界温度域がよ゙の 程度組織の深部に達しているか，および組織内の温度が どのような温度曲線を描くかについて検討した。をそれに よると臨界温度域は粘膜下 $1 \mathrm{~mm}$ から $2 \mathrm{~mm}$ の間にあ り, 温度曲線は冷凍開始後に急激に下降し, $-38^{\circ} \mathrm{C}$ あ たりで横這いとなり，そののちの水解に際しては緩徐に 上昇することがわかった，そこで本実験では冷凍 条件 （室温 $20 \pm 0.5^{\circ} \mathrm{C}$, 湿度 $60 \pm 5 \%$ ，正接法で 1 分間凍結） を一定として組織に与える影響の均一化をはかった。

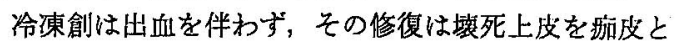
して残したまま行われるため衍後の経過に特異な点がみ られる.

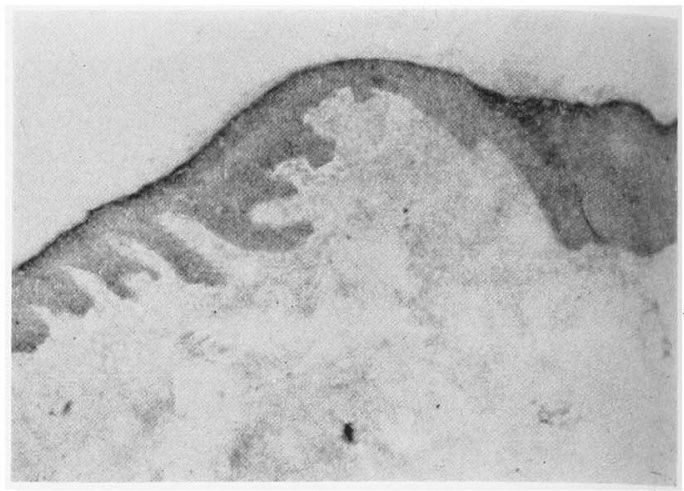

写真 16 凍結後 20 日 G6PDH

\section{1) 浮 腫}

Natiella $ら^{8)}$ は冷涷創を組織学的に険索し術後の著明 な浮腫の出現を特徵の1つとしてあげているが，本実検 でも凍結後24㭙間から 3 日にかけて浮腫特よび炎症緗陶 浸潤が次第に顕著になり，涷結後 3 日がそのピークであ った，さらにこの過程を組織化学的な面, とりわけェネ ルギー代謝に関与する䤃素系からみると，ALPase 活性 は壊死組織直下扣よびそれを取り巻く炎症細胞浸潤部门 一致して認められ，凍結後24時間から3 日にかけてその 活性を強めていき，3日がそのピークで幅の広い帯状下 みられた，創傷といら刺激に対して血管間葉系は敏感に

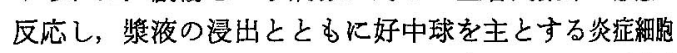
を多数創傷部位に動員させるが，本実験でもこの反応が 特に強くNatiella 5 ${ }^{8)}$ の報告と一致していた，その理

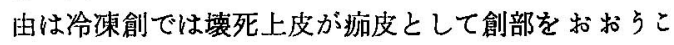
と，また凍結境界部の非谏結側での血管透過性の妄進狩 よびリンパ組織への影響によるものと考えている，この ことは受傷後, 一定時間経過後に創部が血餅でお晾かれ る通常の開放創に比し, 術後経過での大きな相違であ る.

\section{2）治瘾の経過}

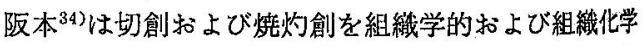
的に険索し，正常動物に打ける口腔粘膜創は術後12時間 から24時間に扔いて高度の急性炎症反応を呈し，2昭 ら4 日において上皮細胞の增殖および間葉組織の修復が 始まる，6日になると組織修復機転が著明となり，12日 から16日で大略治澹するものであると述べている，秋 田 ${ }^{35}$ は外傷治洈機転を 3 期にわけ詳細化報告しており,

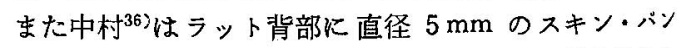
チを施し，その治癒過程を組織学的括よび組䋨化学的に

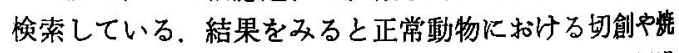

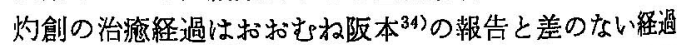
をとっていた。 わたくしの行った実験では，炎症細胞浸 潤部に出現する ALPase 活性は凍結後 3 日がビークで 幅の広い带状に喼められ4 日より消退し始めていたが, 
冷凍創はこの炎症細胞浸潤の期間が長く治洬経過は全体 的に遅延する傾向を示していた。

\section{3) 瘦 痕}

中村 ${ }^{36)}$ や谷㡐37および Kawakatsu ら ${ }^{38)}$ はコラーゲン 合成と ALPase の密な関係について報点しているが， 本実験でも炎症細胞浸潤部に相当する ALPase 活性䏚 性部は凍結後 3 日をピークに 4 日より消退していき, 次 にコラーゲンが新生される凍結後 7 日ごろより再び凍結 部皮下組織に ALPase の強い活性を認めた。このコラ ーゲンの成熟化に密に関与する ALPase 活性は，創部 がほぼ上皮で被覆される凍結後14日ではいまだ高い值を 示し，20日でほほ正常状態に復した。 また G6PDHは 周辺部より修復しつつある新生の上皮顆粒層に強い活性 を示し ${ }^{39,40)}$ ，凍結後14日ごろの創部をほぼ被覆した上皮 でも依然強い活性を残していた。しかし，凍結後20日の 創部上皮が周辺部正常上皮とほぼ同様の厚さに復した時 点では，周囲の上皮と同様の活性に復していた。 上皮は 間質部より栄養をうけているため，創傷治㾏に際しては 間質部の炎症が消退したあとに上皮の伸展が始まるとさ れているが, 冷凍創においても凍結後 7 日ごろより周辺 部からの上皮の伸展がみられた。この上皮の伸展がみら れる凍結後 7 日ごろまで壊死上皮が瘀皮として創部を拈 おっていることは，日常臨休で創露出面の大きな場合に 皮店移植を施し旅痕を防ぐことを考えると，冷凍外科療 法において Poswillo ${ }^{10)}$ が報告している瘢痕形成の少な い点は，この治瘉経過によるものであり唕床所見ともよ く符合していた.

\section{結}

論

正常ラット煩粘膜に冷凍創をつくり組織学的および組 織化学的検索を行い, 次のような結論を得た.

1.プローへ表面の温度と器機裴示のプロー・内櫋の 温度との間に約 $5^{\circ} \mathrm{C}$ の差がみられた。

2. $-20^{\circ} \mathrm{C}$ の臨界温度域はブローべ直下において粘膜 ド $1 \mathrm{~mm}$ から $2 \mathrm{~mm}$ の間にあった。

3. 臨界温度域值下の ALPase 活性は凍結後 3 日ごろ および 7 日ごろの 2 相性に現われ，前者は炎症と後者は コラーゲン合成，特にコラーゲンの成熟化に密に関与し ていた。

4. 冷凍創は炎症細胞浸潤の時期が長く，一般に創傷 治癒は遅れるが，臨㕅的にも組織学的にも瘢痕形成は少 ない.

5. G6PDH は上皮の新生過程とよく符合しており， 伸展しつつある上皮の顆粒層に強い活性を示し，修復さ れた上皮が周辺部正常上皮と同様の厚さに復した時期 に，周囲の上皮と同様の活性に復した。

この論交要旨は，第21 回日本口腔外科学:会総会（昭
利51年10月10日，北九州）および第 253 回大阪㳡科学会 例会（昭利52年 8 月20日，大阪）に扎いて発表した。

なお，稿を終わるにむたり，御校閲をいただいた网野 狩毁教授に深謝し，来た御助言をいただいた飯田武助教

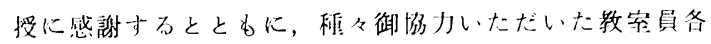

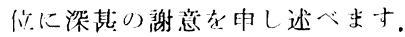

\section{文献}

1) Emmings, F.G., et al.: Cryotherapy for benign lesions of oral cavity. J Oral Surg 25: 320 1976.

2) Emmings, F.G., et al.: Combined curettage and cryotherapy for recurrent ameloblastoma of the mandible. J Oral Surg 29: 411971.

3) Sako, K., et al.: Cryotherapy of intraoral leukoplakia. Amer J Surg 124: 4821972.

4) Gage, A.A., et al.: Cryotherapy for cancer of the lip and oral cavity. Cancer 15: 1646 1965.

5）飯田武，他：煩粘膜部に発生した血管腫（2 例）の冷凍外科療法。口科誌 22：258 1973.

6）飯田 武，他：上顎に発生した中心性佔管腄の 冷凍外科療法。口科誌 23：245 1974.

7）飯田武, 他：Ameloblastoma の罴爬凍結併用 療法。口科誌 21：402 1972.

8) Natiella, J.R., et al.: Tissue response to cryosurgery of oral cavity in rhesus monkeys. Pathol 98: 1831974.

9) Whittaker, D.K.. Cryosurgery of the oral mucosa. A study of the mechanisms of tissue damage. Dent Practit 22: 4451972.

10) Poswillo, D.E.: A comparative study of the effects of electrosurgery and cryosurgery in the management of benign oral lesions. Brit J oral Surg 9: 11971.

11) Shepherd, J.P.: Effects of lowered temperatures on rat pulp and gingivae. Oral Surg 42: 3861976.

12）渡辺邦一：冷谏外科に関する実験的研究。組織 内温度と組織変化。 日外誌 20：51974.

13）天羽 峻：冷凍外科に関寸る実験的研究. 顎骨 内温度と組織変化。日口外誌 21：439 1975.

14）橋本良知：冷凍外科に関する実験的研究. 神経 の損㙏と回復。日口外誌 22：753 1976.

15）阪口嗃：冷凍外科に関吉る実跧的研究，家乘

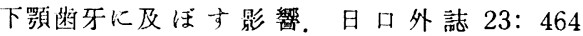
1977.

16）和久勝彦：創愊治嘴に伴５血管の立体的研究. 冷凍外科が血管系に拉よぼす影響。日口外誌 24: 1981978.

17) Iida, T.: The effects of deep freezing on normal and inflamed hamster cheek pouch. J Osaka denı Univ 3: 821969. 
18) Fraser, J., et al.: Observations on ultra frozen tissue. Brit J Surg 54: 7701967.

19）岡野博郎：口腔領域における涑結療法。日将医 師会誌 29：154 1976 .

20) Mandeville, A.F., et al.. Some observations on the cryobiology of blood vessels. Laryngoscope 77: 13281967.

21) Meryman, H.I : Mechanics of freezing living cells and tissuc's. Science 124: 5151956.

22) Armand, M.K., et al.: Tissue freezing. .1 theory for injury and survival. Cryobiologv 2: 991965.

23) Goldwyn, R.M., et al.: ('ryosurgery for large hemangiomas in adults. Plast reconstr Surg 43: 6051969.

24）法虫 炤：クライオサーシェリーと败小循環。 耳喉 44:69 1972.

?巳う) 山田史郎：凍結による皮嗵損伤と回復の細胞動 態論的解析。 日口外誌 19：518 1973.

26）饭田武：冷沚外科の現況。四界展望 48:915 1976.

27）飯田武，他：血管腫に対する Cryosurgery。 日口外誌 23：41 1977.

28）飯田武：口腔領域の冷凍外科。看護技術 18: 1521972

29) Hurt, W.C., ('t al.: Some clinical and histologic observations of gingiva treated by cryotherapy. J Periodont 43: 1511972.
30) Mayers, P.D., et al.: The histological reaction of clinically normal gingiva to freezing. J Periodont 42: 3461971.

31) Grimmett, H.: Liquid nitrogen therapy. Histologic observations. Arch Derm 48: 71967.

32）龟谷寿彦：C'ryosurgery の現況と将来. 外科治 療 28: 4611973.

33）法貴 昭：Cryosurgery. 日耳奥 79：712 1976 .

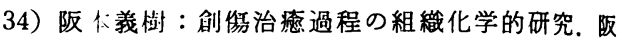
大菌学雑誌 4：643 1959.

35）秋田八年, 他：外倠治捻傤転。最新医学 16: 18501961

36）中村正之：侴僨治演過程におけるグルココルチ

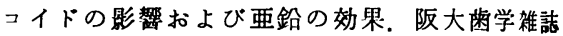
19: 1051974

37）谷岡博炤：創伤治瘜過程の酸性 Phosphataseに 関する組織化学的研究（特にアルカリ性 Phosphatase, Esterase との関係について). 日口外 誌 8: 2681962.

38) Kawakatsu, K., et al.: Histochemical evaluation of enzymatic activities in human squamous cell cancer. Cancer Res 23: 5391963.

39) 岡本次郎：雨液腺多形性腺腫の組織化学的研究。 日口外誌 2:3：212 1977.

40) Mori, M.: Histochemical evaluation of enzymes in ameloblastic tumors-acanthomatous and granular cell ameloblastoma. J Oral Surg 28: 8251970. 